\title{
Three questions: How can taxonomists survive and thrive worldwide?
}

\author{
MICHAEL C. ORR ${ }^{1,2}$, JOHN S. ASCHER ${ }^{3}$, MING BAI ${ }^{1,4}$, DOUGLAS CHESTERS ${ }^{1,5}$ \& CHAO-DONG ZHU ${ }^{1,6,7,8^{*}}$ \\ *Corresponding author:" zhucd@ioz.ac.cn \\ ${ }^{1}$ Key Laboratory of Zoological Systematics and Evolution, Institute of Zoology, Chinese Academy of Sciences, Beijing 100101, P.R. \\ China. \\ ${ }^{2}$ झ" michael.christopher.orr@gmail.com; 으ttp://orcid.org/0000-0002-9096-3008 \\ ${ }^{3}$ Department of Biological Sciences, National University of Singapore, 16 Science Drive 4, 117558, Singapore. ”dbsajs@nus.edu.sg; \\ ○ http://orcid.org/0000-0002-7887-2461 \\ 4 [”baim@ioz.ac.cn; 1 http://orcid.org/0000-0001-9197-5900 \\ ${ }^{5}$ ఏ"dchesters@ioz.ac.cn; $\odot$ http://orcid.org/0000-0001-7352-5770 \\ ${ }^{6}$ State Key Laboratory of Integrated Pest Management, Institute of Zoology, Chinese Academy of Sciences, 1 Beichen West Road, \\ Chaoyang District, Beijing, 100101, P. R. China \\ ${ }^{7}$ College of Biological Sciences, University of Chinese Academy of Sciences, No.19A Yuquan Road, Shijingshan District, Beijing, 10049, \\ P.R. China \\ ${ }^{8}{ }_{\mid="}$ zhucd@ioz.ac.cn; $\odot$ http://orcid.org/0000-0002-9347-3178
}

\begin{abstract}
The science of taxonomy faces many challenges at present. Many questions remain as to how we can best continue the vital practice of describing and understanding biodiversity. Here, we discuss how best to modernize taxonomy, how we might improve taxonomy in developing countries, and how taxonomists can better interface with other fields to better science as a whole.
\end{abstract}

\section{Introduction}

Taxonomy is a foundation of biology and species delimited by taxonomists have been the core units of analysis for centuries (Wilson 2004). Here, we discuss three questions central to the future of taxonomic practices, sequentially building from the basic need for a taxonomic revolution to practical elements of its application regionally and then globally. In the first question, we address how taxonomy is undervalued and how to fix this, essentially, how can we revolutionize taxonomic practices to improve our field? We then focus our second question on how taxonomic practices are best advanced in developing countries, where immense biodiversity remains undescribed; how can we build taxonomic capacity where it is most needed? Finally, we explore how taxonomic and related data can be more effectively unified through a singular species data repository, answering how can we best interface with other sciences?
1. "How can we name species before they go extinct, when taxonomists are also a threatened species?"

We face an unprecedented biodiversity crisis of our own making, via human-induced climate change and myriad habitat alterations or direct harvesting activities, yet we know frighteningly little of what species are being lost (Singh 2002; Yap et al. 2015; Malcom et al. 2019). Hundreds of thousands of invertebrates and even some vertebrates remain undescribed, many unrecognized despite description (unidentifiable), and yet more entirely undiscovered (Giam et al. 2011; Mora et al. 2011; Stork 2018). Under current legislation, if we do not know the name of species, we cannot assess and formally protect them (via IUCN), and hyperdiverse groups such as insects are generally poorly-represented in such assessments (LaSalle \& Gauld 1991; Clausnitzer et al. 2009; Cardoso et al. 2011; Eisenhaur et al. 2019).

Taxonomy, the very field needed to discover, describe, and identify species, is increasingly undervalued, with few funding opportunities and permanent positions available (Lee 2000; Agnarsson \& Kuntner 2007; McClain 2011). Long declines have been suggested in both professional and amateur taxonomists since around the 1950s (Hopkins \& Freckleton 2002), but the situation is complex, as young taxonomists now only rarely advance in academia with traditional practices alone; phylogenetics, functional morphology, etc. are now regular mainstays. For some groups, there even appear to be both more taxonomists and similar numbers of species described as prior (Bacher 2012; Tancoigne \& Dubois 2013), but it is unclear 
whether this will persist. There is no guarantee that students describing species, who may represent many of these describers, will secure positions where they continue describing species; we are unaware of similar analyses accounting for career stage. Consequently, as the last generation retires, there may be too few remaining taxonomists with truly-sustainable positions to train the next generation and carry on this important work.

Taxonomy, as with the life it catalogs, must adapt and evolve to survive and thrive. Crucially, these new methods should focus more on species description to help solve the biodiversity crisis. Although examples of "high-impact" species descriptions exist, they are few and far between outside of fossils and the splitting of well-known species or changing higher taxa (Shu et al. 2003; Berger et al. 2010; Haile-Selassie et al. 2015; Orr et al. 2016; Bai et al. 2018; Su et al. 2018; Yan et al. 2018). This widening gap in taxonomic capacity must be filled by the adoption of powerful, new methods and technologies to revolutionize taxonomy, rather than to replace it.

There is a critical need for taxonomists to expedite both their descriptive and revisionary works with new technologies, as the current rates of description and revision cannot ensure we recognize most species before they go extinct (Bacher 2012, others). Just as vital is identification, as few experts typically exist for any given taxon. DNA barcoding or DNA taxonomy has long been suggested as a solution (Hebert et al. 2003; Tautz et al. 2003), but progress has been incremental both methodologically and outside of over-sampled temperate regions in the Northern Hemisphere (Janzen et al. 2009; Taylor \& Harris 2012; Piper et al. 2019). This can lead to critical reference database gaps, making it impossible to accurately identify specimens to genus, much less species. Consequently, as of Chesters \& Zhu (2014), roughly 194,000 public sequences remained unidentified. Data quality is an entirely different issue, unapproachable in this paper, as many COI pseudogenes are hosted online because authors simply did not check and mitochondrial heteroplasmy also can confound analyses. Regardless, to get these data, many studies rely on directly sequencing all specimens, which can take the majority of a project's work hours and funding (Tang et al. 2015; Yeo et al. 2019). Next-generation methods have been suggested as a highthroughput, lower-cost solution, but only now are powerful metabarcoding and metagenomic methods beginning to show promise for accurately quantifying richness in bulk samples (Lang et al. 2019; Peel et al. 2019; Piper et al. 2019). Low-coverage genome sequencing methods may also prove promising, as then these data can be easily used for phylo- or population genomics, and other purposes (Zhang et al. 2019). Even when perfected, however, these methods will remain detached from formal nomenclature unless sufficient reference sequences exist to 1) delineate species and 2) accurately apply species names. With recent focus on barcoding specimens as well their various associates (microbiome, food sources, parasites, etc.), taxonomic researchers are needed across diverse groups to accurately and efficiently address the biodiversity crisis, even with powerful molecular methods.

The idea of integrative taxonomy, the use of new and varied methods for diagnosing and describing species, is central to a taxonomic revolution (Dayrat 2005). DNA methods have seen intense focus in recent years, but external morphology may actually prove equally useful in the future, especially given that it is non-destructive and more directly linked to functionality. Artificial intelligence image recognition technology has long been suggested for identifying species-rich groups such as insects (Weeks et al. 1999), where cryptic species obscure delimitation even for well-trained taxonomists, but modern machine learning methods are vastly improving prospects (Buschbacher et al. 2019). Though many methods rely on easy-to-quantify features such as wing venation in insects, which are damaged in some specimens of older age or those mass-trapped, improvements in imaging resolution and recognition algorithms increase the range of feasible characters. Indeed, these systems are even being used on citizen science platforms such as iNaturalist, with surprising, ever-increasing accuracy (Robertson et al. 2019). These methods are not limited to traditional approaches focused on exterior characters like color or hair, as internal anatomy is equally or perhaps even more promising for advancing taxonomy. Though taxonomists have written external diagnoses and descriptions for centuries, the vast majority of species have never even been fully dissected, especially smaller, hard-to-dissect specimens. Technologies such as microCT provide incredibly-detailed images of both hard and soft internal structures (Friedrich et al. 2014; Wipfler et al. 2016; Short et al. 2018), enabling better insight than ever before into the interplay of morphology, life history, and speciation.

Together, these morphological data sources hold immense promise not just to complement taxonomy, but to modernize it. Artificial intelligence, once properly trained using images of verified species designated by taxon experts, could easily extract measurements of user-defined characters from images of both external and internal anatomy. Deposited within a central morphological trait database, with multiple individuals per species, these recordings would provide rigorous quantitative diagnostic data and definitions for those species. When specimens are encountered that do not fall within the bounds of known species, they could be flagged as potential new species, verified by taxonomists, and species descriptions could then be automated from the database with greater completeness, comprising many characters and detailed 
measurements, than is seen in any present-day species accounts. Diagnoses could even feasibly be automated by identifying those character combinations which differ most significantly from the most similar species recorded. With the addition of closely-related new species, these diagnoses could even be updated with new information to maintain their usefulness. The first steps have already been taken in some groups, with taxonomic revisions incorporating 3D modeling and imaging techniques (HitaGarcia et al. 2019, Sarnat et al. 2019), but these practices are not yet widespread. With sufficient documentation, it may even be possible for such a system to describe new species solely from citizen science observations. This is not an entirely new idea, as some species image repositories exist (MorphBank 2019; others), and species have already been described from pictures (Marshall \& Evenhuis 2015; Garraffoni \& Freitas 2017). However, due to insufficient detail and myriad other reasons, current approaches are considered lacking (Lobl et al. 2016; Santos et al. 2016; Dubois 2017; Gutiérrez \& Pine 2017). The approach we outline here has the potential to begin bridging this gap when guided by taxonomists, especially when combined with DNA data.

Ultimately, the solutions we present here represent a major shift in the way taxonomy is done, and it will take time for these technologies to become as accessible as traditional taxonomic methods are at present. Nonetheless, we must begin transitioning to this or some other new taxonomic framework, to ensure future approaches maintain the best practices and rigor that underlie traditional taxonomy, as taxonomists may only be able to survive if they guide the changing current rather than be swept away by it.

\section{2. "How can we improve taxonomy in developing countries?"}

The situation is dire for biodiversity in developing countries. As societies and their associated economies develop alongside growing populations (sometimes overpopulation), more land is transformed for agriculture, human habitation, and other forms of infrastructure. This is happening faster than elsewhere because much natural or semi-natural habitat typically remains in these countries, leaving more space for development. Further, landscapes can be transformed far faster in these countries than was ever possible before because developed countries invest in developing countries, transferring technologies to accelerate natural resource extraction, construction, etc. (Kaimowitz 2019). There is much biodiversity yet to be lost, as has already happened in many developed countries where faunal declines are well underway, and all parties involved are responsible (Eisenhaur et al.
2019; Rosenberg et al. 2019; Wagner 2019). Notably, those countries which are currently developed largely contained far fewer species originally than those which are now developing, especially in tropical and subtropical countries for most taxa (Giam et al. 2011; Waldron et al. 2013), so the scale of loss may be immense.

Biodiversity loss will be especially impactful for developing countries, where educational infrastructure is still maturing and the importance of nature may be poorly acknowledged. Animals and plants immensely improve human quality of life through manifold contributions, including decomposition, medicinal or other products, pest control, pollination, etc. (Cardoso et al. 2011; Diaz et al. 2018). Biodiversity is central to food security, a key tenet of developing countries such as China or India where demand is growing. If we cannot identify the species involved in these services and discern their contributions, we cannot easily preserve either. Similarly, new pest species remain undescribed with their natural history unknown, which will be problematic as agriculture and human habitation proliferate (Parsa et al. 2014). This is especially an issue when crops are moved and introduced across natural boundaries, as such pests can be exported as invasives elsewhere, where their detection would be delayed because many of them might be misidentified as other locally-known species that post different threats or have plentiful natural enemies which will not attack the new pests. For these and more reasons, it is imperative that we improve taxonomic capacity in developing countries.

First and foremost, efforts must center on capacity building for local researchers. It is critical that countries become scientifically independent, and developed countries, where such infrastructure already exists, can play a vital role in this process. A central impediment to taxonomy in developing countries is the fact that many type specimens, which underpin the nomenclatural system, reside outside of their home countries. For example, hundreds of bees described by T.D.A. Cockerell from around the globe are now spread across museums in the United States. This means that a researcher in China might need to budget for visiting multiple museums just to see one researcher's types from a single country, including in expensive locations like Washington, D.C. and New York City. Visit funding is crucial as such. Luckily, the primary entomological museums in these areas (National Museum of Natural History and American Museum of Natural History, respectively) are now imaging their type specimens, and some institutions such as Museum für Naturkunde in Berlin have initiated large-scale digitization efforts shared with the public as an exhibition (Naturkunde 2019). Type digitization is a key step that all museums must take to at least minimally digitally "repatriate" taxonomic knowledge to the home regions where infrastructure may not yet exist to safely house them pending building of local expertise and infrastructure, an 
example being the Cambodian Entomology Initiatives (CEI 2019). Similarly, it is also invaluable for museums in developed countries to provide verified reference material to bolster these types of initiatives.

Building local capacity and infrastructure must be a goal, as biological collections are most useful for identification where those species occur. Further, local involvement is vital for knowledge exchange, especially for indigenous knowledge related to classification and conservation which may otherwise be lost, providing clear routes for synergy between outside and local researchers and their communities (Sheil \& Lawrence 2004, Nazarea 2006, Ayala et al. 2013). Similarly, visiting researchers can provide key training in taxonomic practices, collection management, and digitization (Klopper et al. 2002; Smith \& Figueiredo 2009; GBIF 2016). Outside funding will be necessary as well, especially for building suitable collections infrastructure and digitization capability (GBIF 2019). Museums are already underfunded, even in developed countries, so they cannot all be expected to finance such expansive measures. Federal governments are morally obligated to contribute the necessary funding for these efforts, given the extensive role of developed countries in colonialism and other practices, and a centralized biodiversity and taxonomy fund could be raised and administered by an agency such as the Global Environmental Fund or United Nations. These funds could also be used to form regional task forces involving international and local researchers, where direct knowledge transfer would occur as working groups identify and direct resources to solve the mostrelevant problems for different areas. Data centralization and accessibility must also be prioritized, as then efforts would benefit other nearby countries regardless of their direct engagement, while also providing greater incentives for international researchers to devote their time to such efforts. Clearly, much work remains to be done, but we will never finish if we do not start.

The age of extractive expeditionary science conducted without in-country collaborators is ending and it is time for scientists to work together to build capacity worldwide. The Nagoya Protocol and various country-level laws now essentially forbid outside research to varying degrees, making exportation of specimens nigh impossible in many places (Prathapan et al. 2018). Whether this is a net detriment or benefit is a question for another time, but the reality is that we must adapt to changing legislation as lawmakers are unlikely to directly cater to our concerns, as there are obvious economic and societal drivers for countries to maintain and better control their biological resources (biochemical prospecting, prioritizing local researchers, etc.). Sustainable partnerships with dedicated local researchers will be necessary if we are to build a truly global scientific community.

\section{3. "How can we best transform taxonomic data into 'big data'? How can we export taxonomic knowledge to other fields?"}

Taxonomy was the primary biological science for centuries (Wilson 2004). During this time, thousands of researchers and hobbyists compiled more than half a billion preserved specimens (Shortetal.2018) and additional observations of species across the world, including records of distribution, species interactions (diet, parasitism, etc.), morphology, phenology, and much more. However, compared to DNA data, much natural history information remains unused, despite substantial efforts to mobilize these data (GBIF 2016; GBIF 2019; iDigBio 2019; MorphBank 2019; and others). The key difference is that the majority of public genetic data are available from the GenBank platform (NCBI GB 2019), from a single source, early on in the development of this field, rather than being spread across thousands of publications as in the case of natural history information.

Despite these limitations, studies relying on museum specimens or natural history include exploring broadscale patterns and their drivers across life (Isaac et al. 2004), reconstructing population histories with population genomics (Rowe et al. 2011; Bi et al. 2013), detecting declines of bees and other invertebrates as well as their consequences (Gallai et al. 2009; Bartomeus et al. 2013; Eisenhauer et al. 2019), and more. These studies could never have happened without the efforts and guiding knowledge of taxonomists (for asking the right questions, correcting errors, etc.). Even now, much data remains locked away in museums, inventories, species descriptions, natural history accounts, and the minds of us taxonomists. How can we best leverage our knowledge for the betterment of science?

Both of the prior questions allude to innovations which would help us revolutionize taxonomy and improve biology as a whole. Specifically, the digitization of standardized measurements via artificial intelligence and the imaging of all type specimens can, together, form the foundation of a dataset unmatchable in its potential, but there are countless other data types including myriad specimen-related data (phenology, associates, etc.), genetic data, taxonomic or other publications invoking the species, etc., which could also be incorporated into a singular master species data repository. In this system, each species entry would include all relevant information available for that species, such that scientists and citizens alike could learn all they want to know about life on Earth from a single site. The extensions for these data are endless, including direct generation of a continually-updated, datadriven tree of life and similarly "live" models of species richness patterns to enhance conservation planning efforts worldwide. Current attempts can only be considered 
incipient, with resources like Encyclopedia of Life (EOL 2019) insufficiently referencing genetic information, type images, etc. Critically, different sites are splitting efforts and funding resources by trying to accomplish similar goals in slightly different ways (providing different data types or categorizations, focusing on different taxa or areas), but such a grand scheme is only achievable through unified efforts. At the same time, citizen science portals such as DiscoverLife (2019), iNaturalist (2019), and BugGuide (2019) have built new, dynamic, and complementary tools, especially regarding empowering of numerous virtual curators (ideally taxonomists) to ensure data quality, that could be usefully applied to this centralized system so as to greatly improve their reliability and usability.

This enterprise would obviously require immense infrastructural and funding support, especially given the need for rigorous validations (Costello et al. 2013; Costello \&Wiekzorek 2014), but it is not impossible, when considering the enormous success of the GenBank platform (NCBI GB 2019) and current efforts to mobilize collections data (Cobb et al. 2019). The task of aggregating all such data is also no easy task, but it will only get harder in the future, especially given the accelerated rate of scientific publications in the last few decades (Larsen \& Von Ins 2010), making a unified species data system an absolute imperative for both taxonomists and biologists in general.

Perhaps the most important concern underlying this and the first question is how collaborative arrangements can be made equitable for all parties. At first glance, then, the idea of a unified repository for species information may seem detrimental to taxonomy, as this would make it easier for other researchers to access massive quantities of all data types, potentially removing taxonomists from the process altogether once the database is sufficient for their given taxon (thereby preventing engagement with the crucial taxon experts needed for data generation and validation). The key check upon this process would be usage agreements between researchers as well as nonscientific users such as conservationists and policymakers. Although all hosted data would be searchable, with vital resources such as type images mandated public, some would remain inaccessible without data-owner permission (e.g., non-public distributional checklists, unpublished genome assemblies, or some trait datasets such as in TRY 2019). This would grant taxonomists much greater reach and visibility to data users while also enabling them to exercise more control over how their data are actually used. Each species entry could also act as a citable online object, providing additional benefits to taxonomists via increasing additional publications and metrics such as $\mathrm{H}-$ index that are presently important for career development in academia (whether this is a good thing is an entirely different matter). Further, researchers could also avoid unintentional competition on specific topics, instead opting for collaboration, and non-taxonomists would be far better informed about what data exist, not just which are made public. Direct linkage between researchers would also encourage back-and-forth dialog, such that taxonomic knowledge can inform parameter selection and model calibration in ecological analyses. Although truly open science is a noble goal, where all data are immediately freely available, data generators simply will not participate without increased recognition and support enabled by this type of infrastructure. This program has the potential to once more center taxonomic knowledge within biology, while also providing funding and contracts for involved taxonomists, such that the next generation of researchers can continue their vital work and ultimately solve the biodiversity crisis.

\section{Acknowledgements}

We thank Dr. Alice C. Hughes for valuable discussions and support. Dr. Zhi-Qiang Zhang is thanked for his kind invitation, and he and Dr. Celso Azevedo are thanked for their improvements of the manuscript.

\section{Funding}

M.C.O, D.C., and C.D.Z. were mainly supported by grants from the National Science Foundation, China (31625024, $41761144068,31772495)$, and the Key Laboratory of Zoological Systematics and Evolution, Chinese Academy of Sciences (Y229YX5105). Other supports include the Research Fund for International Young Scientists NSFC 31850410464 and the CAS PIFI 2018PB0003 (to M.C.O); NSFC 31961143002 (to M.B.); and NRF2017NRFNSFC001-015 (to J.S.A.).

\section{Author contributions}

C.D.Z., M.C.O., and D.C. conceived the questions. M.C.O. wrote the initial draft. Every author commented on and contributed to subsequent drafts. All authors approved the final submission.

\section{References}

Agnarsson, I. \& Kuntner, M. (2007) Taxonomy in a changing world: seeking solutions for a science in crisis. Systematic Biology, 56 (3), 531-539.

https://doi.org/10.1080/10635150701424546 
Ayala, R., Gonzalez, V.H. \& Engel, M.S. (2013) Mexican stingless bees (Hymenoptera: Apidae): diversity, distribution, and indigenous knowledge. In: Smith, X. \& Adam, Y. (eds) PotHoney. Springer, New York, pp. 135-152.

Bacher, S. (2012) Still not enough taxonomists: reply to Joppa et al. Trends in Ecology \& Evolution, 27 (2), 65-66. https://doi.org/10.1016/j.tree.2011.11.003

Bai, M., Beutel, R.G., Zhang, W., Wang, S., Hörnig, M., Gröhn, C., Yan, E., Yang, X. \& Wipfler, B. (2018) A new Cretaceous insect with a unique cephalo-thoracic scissor device. Current Biology, 28 (3), 438-443.

https://doi.org/10.1016/j.cub.2017.12.031

Bartomeus, I., Ascher, J.S., Gibbs, J., Danforth, B.N., Wagner, D.L., Hedtke, S.M. \& Winfree, R. (2013) Historical changes in northeastern US bee pollinators related to shared ecological traits. Proceedings of the National Academy of Sciences, 110 (12), 4656-4660. https://doi.org/10.1073/pnas. 1218503110

Berger, L.R., De Ruiter, D.J., Churchill, S.E., Schmid, P., Carlson, K.J., Dirks, P.H. \& Kibii, J.M. (2010) Australopithecus sediba: a new species of Homo-like australopith from South Africa. Science, 32 (5975), 195-204. https://doi.org/10.1126/science.1184944

Bi, K., Linderoth, T., Vanderpool, D., Good, J.M., Nielsen, R. \& Moritz, C. (2013) Unlocking the vault: next-generation museum population genomics. Molecular Ecology, 22 (24), 6018-6032. https://doi.org/10.1111/mec.12516

BugGuide. (2019) BugGuide.net. Available from: https://bugguide. net/node/view/15740 (accessed December 2019)

Buschbacher, K., Ahrens, D., Espeland, M. \& Steinhage, V. (2019) Image-based species identification of wild bees using convolutional neural networks. Ecological Informatics, 101017. https://doi.org/10.1016/j.ecoinf.2019.101017

Cardoso, P., Erwin, T.L., Borges, P.A. \& New, T.R. (2011) The seven impediments in invertebrate conservation and how to overcome them. Biological Conservation, 144 (11), 26472655.

https://doi.org/10.1016/j.biocon.2011.07.024

CEI. (2019) Cambodian Entomology Initiatives. Available from: http://www.cambodianentomology.org/ (accessed December 2019).

Chesters, D. \& Zhu, C.D. (2014) A protocol for species delineation of public DNA databases, applied to the Insecta. Systematic Biology, 63 (5), 712-725. https://doi.org/10.1093/sysbio/syu038

Clausnitzer, V., Kalkman, V.J., Ram, M., Collen, B., Baillie, J.E., Bedjanič, M., Darwall, W.R.T., Dijkstra, K.D.B., Dow, R., Hawking, J., Karube, H., Malikova, E., Paulson, D., Schutte, K., Suhling, F., Villanueva, R.J., von Ellenrieder, N. \& Karube, H. (2009) Odonata enter the biodiversity crisis debate: the first global assessment of an insect group. Biological Conservation, 142 (8), 1864-1869. https://doi.org/10.1016/j.biocon.2009.03.028

Cobb, N.S., Gall, L.F., Zaspel, J.M., Dowdy, N.J., McCabe, L.M. \& Kawahara, A.Y. (2019) Assessment of North American arthropod collections: prospects and challenges for addressing biodiversity research. PeerJ, 7, e8086. https://doi.org/10.7717/peerj.8086

Costello, M.J., Michener, W.K., Gahegan, M., Zhang, Z.Q. \& Bourne, P.E. (2013) Biodiversity data should be published, cited, and peer reviewed. Trends in Ecology \& Evolution, 28
(8), 454-461.

https://doi.org/10.1016/j.tree.2013.05.002

Costello, M.J. \& Wieczorek, J. (2014) Best practice for biodiversity data management and publication. Biological Conservation, $173,68-73$. https://doi.org/10.1016/j.biocon.2013.10.018

Dayrat, B. (2005) Towards integrative taxonomy. Biological Journal of the Linnean Society, 85 (3), 407-417. https://doi.org/10.1111/j.1095-8312.2005.00503.x

Díaz, S., Pascual, U., Stenseke, M., Martín-López, B., Watson, R.T., Molnár, Z., Hill, R., Chan, K.M.A., Baste, I.A., Brauman, K.A., Polasky, S., Church, A., Lonsdale, M., Larigauderie, A., Leadley, P.W., van Oudenhoven, A.P.E., van der Plaat, F., Schröter, M., Lavorel, S., AumeeruddyThomas, Y., Bukvareva, E., Davies, K., Demissew, S., Erpul, G., Failler, P., Guerra, C.A., Hewitt, C.L., Keune, H., Lindley, S. \& Shirayama, Y. (2018) Assessing nature's contributions to people. Science, 359 (6373), 270-272.

https://doi.org/10.1126/science.aap 8826

DiscoverLife. (2019) Discover Life. Available from: https://www. discoverlife.org/ (accessed December 2019).

Dubois, A. (2017) The need for reference specimens in zoological taxonomy and nomenclature. Bionomina, 12 (1), 4-38. http://dx.doi.org/10.11646/bionomina.12.1.2

Eisenhauer, N., Bonn, A. \& Guerra, C.A. (2019) Recognizing the quiet extinction of invertebrates. Nature Communications, 10 (1), 50 . https://doi.org/10.1038/s41467-018-07916-1

EOL. (2019) Encyclopedia of Life. Available from: https://eol.org/ (accessed December 2019).

Friedrich, F., Matsumura, Y., Pohl, H., Bai, M., Hörnschemeyer, T. \& Beutel, R.G. (2014) Insect morphology in the age of phylogenomics: innovative techniques and its future role in systematics. Entomological Science, 17 (1), 1-24. https://doi.org/10.1111/ens. 12053

Gallai, N., Salles, J.M., Settele, J. \& Vaissière, B.E. (2009) Economic valuation of the vulnerability of world agriculture confronted with pollinator decline. Ecological Economics, 68 (3), 810-821. https://doi.org/10.1016/j.ecolecon.2008.06.014

Garraffoni, A.R.S. \& Freitas, A.V.L. (2017) Photos belong in the taxonomic Code. Science, 355 (6327), 805-805. https://doi.org/10.1126/science.aam7686

GBIF. (2016) African Insect Atlas digitization training meeting: from specimens to publishing. Available from: https://www. gbif.org/event/82805/african-insect-atlas-digitizationtraining-meeting-from-specimens-to-publishing (accessed December 2019).

GBIF. (2019) Global Biodiversity Information Facility: Biodiversity Information Fund for Asia. Available from: https://www.gbif. org/programme/82629/bifa-biodiversity-information-fundfor-asia (accessed December 2019).

Giam, X., Scheffers, B.R., Sodhi, N.S., Wilcove, D.S., Ceballos, G. \& Ehrlich, P.R. (2011) Reservoirs of richness: least disturbed tropical forests are centres of undescribed species diversity. Proceedings of the Royal Society B: Biological Sciences, 279 (1726), 67-76. https://doi.org/10.1098/rspb.2011.0433

Gutiérrez, E.C. \& Pine, R.H. (2017) Specimen collection crucial to taxonomy. Science, 355 (6331), 1275. https://doi.org/10.1126/science.aan0926

Haile-Selassie, Y., Gibert, L., Melillo, S.M., Ryan, T.M., Alene, M., Deino, A., Levin, N.E., Scott, G. \& Saylor, B.Z. (2015) 
New species from Ethiopia further expands Middle Pliocene hominin diversity. Nature, 521 (7553), 483.

https://doi.org/10.1038/nature14448

Hebert, P.D., Ratnasingham, S. \& De Waard, J.R. (2003) Barcoding animal life: cytochrome $\mathrm{c}$ oxidase subunit 1 divergences among closely related species. Proceedings of the Royal Society of London. Series B: Biological Sciences, 270, S96S99. https://doi.org/10.1098/rsbl.2003.0025

Hita-Garcia, F., Lieberman, Z., Audisio, T.L., Liu, C. \& Economo, E.P. (2019) Revision of the Highly Specialized Ant Genus Discothyrea (Hymenoptera: Formicidae) in the Afrotropics with X-Ray Microtomography and 3D Cybertaxonomy. Insect Systematics and Diversity, 3 (6), 5. https://doi.org/10.1093/isd/ixz015

Hopkins, G.W. \& Freckleton, R.P. (2002) Declines in the numbers of amateur and professional taxonomists: implications for conservation. In: Animal Conservation forum. Vol. 5, No. 3 . Cambridge University Press, Cambridge, pp. 245-249.

iDigBio. (2019) iDigBio: Integrated Digitized Biocollections. Available from: https://www.idigbio.org/ (accessed December 2019)

iNaturalist. (2019) A community for naturalists: iNaturalist. Available from: https://www.inaturalist.org/ (accessed December 2019).

Isaac, N.J., Mallet, J. \& Mace, G.M. (2004) Taxonomic inflation: its influence on macroecology and conservation. Trends in Ecology \& Evolution, 19 (9), 464-469. https://doi.org/10.1016/j.tree.2004.06.004

Janzen, D.H., Hallwachs, W., Blandin, P., Burns, J.M., Cadiou, J.M., Chacon, I., Dapkey, T., Deans, A.R., Epstein, M.E., Espinoza, B., Franclemont, J.G., Haber, W.A., Hajibabaei, M., Hall, J.P.W., Hebert, P.D.N., Gauld, I.D., Harvey, D.J., Hausmann, A., Kitching, I.J., Lafontaine, D., Landry, J.-F., Lemaire, C., Miller, J.Y., Miller, J.S., Miller, L., Miller, S.E., Montero, J., Munroe, E., Green, S.R., Ratnasingham, S., Rawlins, J.E., Robbins, R.K., Rodriguez, J.J., Rougerie, R., Sharkey, M.J., Smith, M.A., Solis, M.A., Sullivan, J.B., Thiaucourt, P., Wahl, D.B., Weller, S.J., Whitfield, J.B., Willmott, K.R., Wood, D.M., Woodley, N.E. \& Wilson, J.J. (2009) Integration of DNA barcoding into an ongoing inventory of complex tropical biodiversity. Molecular Ecology Resources, 9, 1-26. https://doi.org/10.1111/j.1755-0998.2009.02628.x

Kaimowitz, D. (Ed.). (2019) Making the link: Agricultural research and technology transfer in developing countries. CRC Press, Boca Raton, USA. 278 pp.

Klopper, R.R., Smith, G.F. \& Chikuni, A.C. (2002) The global taxonomy initiative in Africa. Taxon, 51 (1), 159-165. https://doi.org/10.2307/1554974

Larsen, P. \& Von Ins, M. (2010) The rate of growth in scientific publication and the decline in coverage provided by Science Citation Index. Scientometrics, 84 (3), 575-603. https://doi.org/10.1007/s11192-010-0202-Z

Lang, D., Tang, M., Hu, J. \& Zhou, X. (2019) Genome-skimming provides accurate quantification for pollen mixtures. Molecular Ecology Resources, 19 (6), 1433-1446. https://doi.org/10.1111/1755-0998.13061

LaSalle, J. \& Gauld, I.D. (1991) Parasitic Hymenoptera and the biodiversity crisis. Redia, 74 (3), 315-334.

Lee, M.S. (2000) A worrying systematic decline. Trends in Ecology \& Evolution, 15 (8), 346. https://doi.org/10.1016/S0169-5347(00)01907-8

Löbl, I., Cibois, A. \& Landry, B. (2016) Describing new species in the absence of sampled specimens: a taxonomist's owngoal. The Bulletin of Zoological Nomenclature, 73 (1), 8387.

https://doi.org/10.21805/bzn.v73i1.a2

Malcom, J., Schwartz, M.W., Evansen, M., Ripple, W.J., Polasky, S., Gerber, L.R., Lovejoy, T.E., Talbot, L.M. \& Miller, J.R. (2019) Solve the biodiversity crisis with funding. Science, 365 (6459), 1256-1256.

https://doi.org/10.1126/science.aay9839

Marshall, S.A. \& Evenhuis, N.L. (2015) New species without dead bodies: a case for photo-based descriptions, illustrated by a striking new species of Marleyimyia Hesse (Diptera, Bombyliidae) from South Africa. ZooKeys, 525, 117-127. https://doi.org/10.3897/zookeys.525.6143

McClain, C. (2011) The mass extinction of scientists who study species. Wired Science, 19 (01). Available from: https://www. wired.com/2011/01/extinction-of-taxonomists/ (accessed November 2019).

Mora, C., Tittensor, D.P., Adl, S., Simpson, A.G. \& Worm, B. (2011) How many species are there on Earth and in the ocean?. PLoS Biology, 9 (8), e1001127.

https://doi.org/10.1371/journal.pbio.1001127

MorphBank. (2019) MorphBank : Biological Imaging. Available from: https://www.morphbank.net/index.php (accessed December 2019).

Naturkunde. (2019) A collection opens: Live digitization of insects in the exhibition. Available from: https://www. museumfuernaturkunde.berlin/en/press/press-releases/ collection-opens-live-digitization-insects-exhibition (accessed December 2019).

Nazarea, V.D. (2006) Local knowledge and memory in biodiversity conservation. Annual Review of Anthropology, 35, 317-335. https://doi.org/10.1146/annurev.anthro.35.081705.123252

NCBI GB. (2019) National Center for Biotechnology Information GenBank. Available from: https://www.ncbi.nlm.nih.gov/ genbank/ (accessed December 2019).

Orr, M.C., Griswold, T., Pitts, J.P. \& Parker, F.D. (2016) A new bee species that excavates sandstone nests. Current Biology, 26 (17), R792-R793. https://doi.org/10.1016/j.cub.2016.08.001

Parsa, S., Morse, S., Bonifacio, A., Chancellor, T.C., Condori, B., Crespo-Pérez, V., Hobbs, S.L.A., Kroschel, J., Ba, M.N., Rebaudo, F., Sherwood, S.G., Vanek, S.J., Faye, E., Herrera, M.A. \& Dangles, O. (2014) Obstacles to integrated pest management adoption in developing countries. Proceedings of the National Academy of Sciences, 111 (10), 3889-3894. https://doi.org/10.1073/pnas.1312693111

Piper, A.M., Batovska, J., Cogan, N.O., Weiss, J., Cunningham, J.P., Rodoni, B.C. \& Blacket, M.J. (2019) Prospects and challenges of implementing DNA metabarcoding for highthroughput insect surveillance. GigaScience, 8 (8), giz092. https://doi.org/10.1093/gigascience/giz092

Prathapan, K.D., Pethiyagoda, R., Bawa, K.S., Raven, P.H., Rajan, P.D., Acosta, L.E., Adams, B., Adl, S., Ahyong, S.T., Anderson, R., Arango, C.P., Arnedo, M.A., Armbruster, J.W., Avila, L.J., Azevedo, C.O., Baldo, D., Barclay, M.V.L., BaronSzabo, R., Bauer, A.M., Bentlage, B., Bezdek, A., Bird, G., Blagoderov, V., Bocak, L., Bonaldo, A., Bond, J.E., Borkent, C.J., Branham, M.A., Carranza, S., Carreno, R., de Carvalho, M.R., Castroviejo-Fisher, S., Chiba, H., Ciampor, F., Clarke, D.J., Collins, A.G., Constantino, R., Crespo, F.A., Daly, M., Dominiak, P., Dronen, N., Dubois, A., Duda, T.F., Eleaume, M., Erlacher, S., Estrela, P.C., Evenhuis, N., Fehlauer-Ale, 
K.H., Fery, H., Fritz, U., Gaimari, S.D., Garrison, R., Gaubert, P., Geiger, D.L., Gill, A.C., Gimmel, M.L., Goldschmidt, T., Goswami, R., Gonzalez, A.P., Gonzalez, V.H., Gordon, D., Gower, D.J., Greenslade, P., Gusarov, V.I., Hajdu, E., Harms, D., Heinicke, M.P., Hilton, E.J., Hodgson, C.J., Hormiga, G., Hughes, L.E., Hutchings, P., Jager, P., Jennings, J.T., Kadej, M., Kaila, L., Kaminski, M.J., Karaman, G.S., Karanovic, T., Kathirithamby, J., Kerr, P.H., Kirkendall, L.R., Kitahara, M.V., Klautau, M., Kondratieff, B.C., Kroh, A., Labarque, F.M., Leavengood, J.M., Letardi, A., Liang, A.-P., Lima, F.C.T., Liu, Z., Lobl, I., Lohrmann, V., Malchus, N., Malipatil, M.B., Marques, A.C., Matzke-Karasz, R., Mayer, G., Mayoral, J.G., McInnes, S.J., Minelli, A., Moir, M.L., Monks, S., Morrone, J.J., Muster, C., Nagy, Z.T., Narayanan, K.S., Nearns, E.H., Nekola, J., Nihei, S.S., Nutzel, A., Ohler, A., Orrico, V.G.D., Padial, J.M., Page, L.M., Passos, P., Paulson, D., Perkins, P.D., Pfingstl, T., Prieto, C., Pinheiro, L.R., Pinto-da-Rocha, R., Prendini, L., Price, B., Prins, J.D., Ramirez, M., Rasmussen, C., Rasmussen, P., Redei, D., Ribera, I., Ricarte, A., Rivera, J., Rix, M.G., Rossaro, B., Roy, A.D., Ruiz, G.R.S., Salles, F.F., Sanborn, A.F., Sartori, M., Scholler, M., Schmelz, R.M., Schrodl, M., Segniagbeto, G.H., Serrano, J., Shimano, S., Shin, M.K., Sidorchuk, E., Siler, C.D., Sket, B., Smith, A.D., Smith, A.B.T., Smith, R., Smith-Pardo, A.H., Sparks, J., Sterrer, W.E., Stroinski, A., Svavarsson, J., Toledo, M., Twomey, E., Vasudevan, K., Vences, M., de Voogd, N., Wang, Q., Watson, G.W., Weiner, W.M., Weksler, M., Wesener, T., Whitmore, D., Wiklund, H., Williams, P.H., Winterton, S.L., Wood, T.S., Yen, S.-H., Zaher, H., Zhang, Z.-Q. \& Zhou, H.-Z. (2018) When the cure kills - CBD limits biodiversity research. Science, 360 (6396), 1405-1406. https://doi.org/10.1126/science.aat9844

Robertson, T., Belongie, S., Hartwig, A., Kaeser-Chen, C., Zhang, C., Tan, K.C., Liu, Y., Brule, D., Deltheil, C., Loarie, S., Van Horn, G., Aodha, O.M., Beery, S., Perona, P., Copas, K. \& Waller, J.T. (2019) Training Machines to Identify Species using GBIF-mediated Datasets. Biodiversity Information Science and Standards, 3, 37230. http://doi.org/10.3897/biss.3.37230

Rosenberg, K.V., Dokter, A.M., Blancher, P.J., Sauer, J.R., Smith, A.C., Smith, P.A., Stanton, J.C., Panjabi, A., Helft, L., Parr, M. \& Marra, P.P. (2019) Decline of the North American avifauna. Science, 366 (6461), 120-124. https://doi.org/10.1126/science.aaw1313

Rowe, K.C., Singhal, S., Macmanes, M.D., Ayroles, J.F., Morelli, T.L., Rubidge, E.M., Bi, K. \& Moritz, C.C. (2011) Museum genomics: low-cost and high-accuracy genetic data from historical specimens. Molecular Ecology Resources, 11 (6), 1082-1092.

https://doi.org/10.1111/j.1755-0998.2011.03052.x

Santos, C.M.D., Amorim, D.D.S., Klassa, B., Fachin, D.A., Nihei, S.S., De Carvalho, C.J., Falaschi, R.L., Mello-Patiu, C.A., Couri, M.S., Oliveira, S.S., Silva, V.C., Ribeiro, G.C., Capellari, R.S. \& Lamas, C.J.E. (2016) On typeless species and the perils of fast taxonomy. Systematic Entomology, 41 (3), 511-515.

https://doi.org/10.1111/syen.12180

Sarnat, E.M., Hita Garcia, F., Dudley, K., Liu, C., Fischer, G. \& Economo, E.P. (2019) Ready Species One: exploring the use of augmented reality to enhance systematic biology with a revision of Fijian Strumigenys (Hymenoptera: Formicidae). Insect Systematics and Diversity, 3 (6), 6. https://doi.org/10.1093/isd/ixz005
Sheil, D. \& Lawrence, A. (2004) Tropical biologists, local people and conservation: new opportunities for collaboration. Trends in Ecology \& Evolution, 19(12), 634-638.

https://doi.org/10.1016/j.tree.2004.09.019

Short, A.E.Z., Dikow, T. \& Moreau, C.S. (2018) Entomological collections in the age of big data. Annual Review of Entomology, 63, 513-530.

https://doi.org/10.1146/annurev-ento-031616-035536

Shu, D., Morris, S.C., Zhang, Z.F., Liu, J.N., Han, J., Chen, L., Zhang, X.L., Yasui, K. \& Li, Y. (2003) A new species of yunnanozoan with implications for deuterostome evolution. Science, 299 (5611), 1380-1384.

https://doi.org/10.1126/science. 1079846

Singh, J.S. (2002) The biodiversity crisis: a multifaceted review. Current Science, 82 (6), 638-647.

Smith, G.F. \& Figueiredo, E. (2009) Capacity building in taxonomy and systematics. Taxon, 58 (3), 697-699.

https://doi.org/10.1002/tax.583001

Su, T., Farnsworth, A., Spicer, R.A., Huang, J., Wu, F.X., Liu, J., Li, S.-F., Xing, Y.-W., Huang, Y.-J., Deng, W.-Y.-D., Tang, H., Xu, C.-L., Zhao, F., Srivastava, G., Valdes, P.J., Deng, T. \& Zhou, Z.-K. (2019) No high Tibetan Plateau until the Neogene. Science Advances, 5 (3), eaav2189.

https://doi.org/10.1126/sciadv.aav2189

Stork, N.E. (2018) How many species of insects and other terrestrial arthropods are there on Earth?. Annual Review of Entomology, 63, 31-45. https://doi.org/10.1146/annurev-ento-020117-043348

Tancoigne, E. \& Dubois, A. (2013) Taxonomy: no decline, but inertia. Cladistics, 29 (5), 567-570. https://doi.org/10.1111/cla.12019

Tang, M., Hardman, C. J., Ji, Y., Meng, G., Liu, S., Tan, M., Yang, S., Moss, E.D., Wang, J., Yang, C., Bruce, C., Nevard, T., Potts, S.G., Zhou, X. \& Yu, D.W. (2015) High-throughput monitoring of wild bee diversity and abundance via mitogenomics. Methods in Ecology and Evolution, 6 (9), 1034-1043.

https://doi.org/10.1111/2041-210X.12416

Tautz, D., Arctander, P., Minelli, A., Thomas, R.H. \& Vogler, A.P. (2003) A plea for DNA taxonomy. Trends in Ecology and Evolution, 18 (2), 70-74. https://doi.org/10.1016/S0169-5347(02)00041-1

Taylor, H.R. \& Harris, W.E. (2012) An emergent science on the brink of irrelevance: a review of the past 8 years of DNA barcoding. Molecular Ecology Resources, 12 (3), 377-388. https://doi.org/10.1111/j.1755-0998.2012.03119.x

TRY. (2019) TRY Plant Trait Database. Available from: https:// www.try-db.org/TryWeb/Home.php (accessed December 2019).

Wagner, D.L. (2019) Insect declines in the Anthropocene. Annual Review of Entomology, 65. [Review in Advance.] https://doi.org/10.1146/annurev-ento-011019-025151

Waldron, A., Mooers, A.O., Miller, D.C., Nibbelink, N., Redding, D., Kuhn, T.S., Roberts, J.T. \& Gittleman, J.L. (2013) Targeting global conservation funding to limit immediate biodiversity declines. Proceedings of the National Academy of Sciences, 110 (29), 12144-12148. https://doi.org/10.1073/pnas.1221370110

Weeks, P.J.D., O’Neill, M.A., Gaston, K.J. \& Gauld, I.D. (1999) Automating insect identification: exploring the limitations of a prototype system. Journal of Applied Entomology, 123 (1), $1-8$. https://doi.org/10.1046/j.1439-0418.1999.00307.x 
Wilson, E.O. (2004) Taxonomy as a fundamental discipline. Philosophical Transactions of the Royal Society of London. Series B: Biological Sciences, 359 (1444), 739-739. https://doi.org/10.1098/rstb.2003.1440

Wipfler, B., Pohl, H., Yavorskaya, M.I. \& Beutel, R.G. (2016) A review of methods for analysing insect structures - the role of morphology in the age of phylogenomics. Current Opinion in Insect Science, 18, 60-68.

https://doi.org/10.1016/j.cois.2016.09.004

Yan, F., Lü, J., Zhang, B., Yuan, Z., Zhao, H., Huang, S., Wei, G., Mi, X., Zou, D., Xu, W., Chen, S., Wang, J., Xie, F., Wu, M., Xiao, H., Liang, Z., Jin, J., Wu, S., Xu, C., Tapley, B., Turvey, S.T., Papenfuss, T.J., Cunningham, A.A., Murphy, R.W., Zhang, Y. \& Che, J. (2018) The Chinese giant salamander exemplifies the hidden extinction of cryptic species. Current
Biology, 28 (10), R590-R592.

https://doi.org/10.1016/j.cub.2018.04.004

Yeo, D., Srivathsan, A. \& Meier, R. (2019) Mini-barcodes are more suitable for large-scale species discovery in Metazoa than full-length barcodes. bioRxiv, 594952.

https://doi.org/10.1101/594952

Yap, T.A., Koo, M.S., Ambrose, R.F., Wake, D.B. \& Vredenburg, V.T. (2015) Averting a North American biodiversity crisis. Science, 349 (6247), 481-482. https://doi.org/10.1126/science.aab1052

Zhang, F., Ding, Y., Zhu, C.D., Zhou, X., Orr, M.C., Scheu, S. \& Luan, Y.X. (2019) Phylogenomics from low-coverage wholegenome sequencing. Methods in Ecology and Evolution, 10 (4), 507-517.

https://doi.org/10.1111/2041-210X.13145 